\title{
The predictive value of serum myeloma protein in solitary plasmacytoma
}

\author{
Won Ick Chang', Hyeon Kang Koh ${ }^{2}$, Sung-Soo Yoon ${ }^{3}$, Han-Soo Kim ${ }^{4}$ Keun-Yong Eom ${ }^{6}$, II Han Kim ${ }^{1,5}$ \\ 'Department of Radiation Oncology, Seoul National University College of Medicine, Seoul, Korea \\ ${ }^{2}$ Department of Radiation Oncology, Konkuk University Medical Center, Seoul, Korea \\ ${ }^{3}$ Department of Internal Medicine, Seoul National University College of Medicine, Seoul, Korea \\ ${ }^{4}$ Department of Orthopedic Surgery, Seoul National University College of Medicine, Seoul, Korea \\ ${ }^{5}$ Cancer Research Institute, Seoul National University, Seoul, Korea \\ ${ }^{6}$ Department of Radiation Oncology, Seoul National University Bundang Hospital, Seongnam, Korea
}

Received: October 28, 2019

Revised: April 29, 2020

Accepted: May 26, 2020

Correspondence:

II Han Kim

Department of Radiation Oncology,

Seoul National University College of

Medicine, 101 Daehak-ro, Jongno-gu,

Seoul 03080, Korea.

Tel: +82-2-2072-2528

Fax: +82-2-765-3317

E-mail: ihkim@snu.ac.kr

ORCID:

https://orcid.org/0000-0002-4755-5201
Purpose: To identify the clinical usefulness of serum $\mathrm{M}$ protein and to establish a rationale for regular follow-up with serum protein electrophoresis in solitary plasmacytoma.

Materials and Methods: Sixty-nine patients with solitary plasmacytoma and solitary plasmacytoma with minimal marrow involvement according to the International Myeloma Working Group criteria were retrospectively reviewed.

Results: At a median follow-up of 6.2 years, 5-year local control (LC), 5-year multiple myeloma-free survival (MMFS), 5-year failure-free survival (FFS), and 5-year overall survival (OS) were $82.6 \%$, $44.1 \%, 41.8 \%$, and $85.1 \%$, respectively. Among the patients whose initial serum $M$ protein was present or not evaluated, $37.3 \%$ of patients showed disappearance of serum $M$ protein after various treatment. MMFS of these patients were comparable to non-secretory plasmacytoma with undetectable levels of $M$ protein, and significantly better than patients with persistent $M$ protein. Increase of serum $\mathrm{M}$ protein $\geq 0.1 \mathrm{~g} / \mathrm{dL}$ was most predictive of treatment failure with area under the curve of 0.731 .

Conclusion: Patients who eventually showed persistence of serum $\mathrm{M}$ protein after treatment showed worse MMFS and FFS compared to those whose serum M protein disappeared or who had initially non-secretory disease. The increase of serum $M$ protein level $\geq 0.1 \mathrm{~g} / \mathrm{dL}$ from current nadir was predictive of treatment failure. Therefore, regular follow-up with serum $\mathrm{M}$ protein is highly recommended especially unless the patient had initially non-secretory disease.

Keywords: Plasmacytoma, Myeloma protein, Risk factor, Radiotherapy

\section{Introduction}

Solitary plasmacytoma is a rare disease which accounts for less than $10 \%$ of plasma cell neoplasm [1]. It is diagnosed at a median age of 60 and is a male-dominant disease with a male to female ratio of approximately 2:1 [2,3]. Solitary plasmacytoma is subdivided into two disease entities. Solitary plasmacytoma originating from bones are classified as solitary plasmacytoma of the bone (SPB), whereas soft tissue origin plasmacytoma is classified as soli- tary extramedullary plasmacytoma (SEP). While SPB is most frequently observed in the axial skeleton, such as vertebra, SEP is commonly found in the head and neck, especially in the upper aerodigestive tract $[2,3]$.

Owing to its rarity, there were no randomized trials to identify the standard treatment for solitary plasmacytoma. Although multiple myeloma ( $\mathrm{MM})$ is generally treated with chemotherapy and is thought to be incurable, solitary plasmacytoma is treated well with excellent 5-year local control (LC) rate ranging from 81 to 95\% af-

Copyright@ 2020 The Korean Society for Radiation Oncology

This is an Open Access article distributed under the terms of the Creative Commons Attribution Non-Commercial License (http://creativecommons.org/licenses/by-nc/4.0/) which permits unrestricted non-commercial use, distribution, and reproduction in any medium, provided the original work is properly cited. 
ter local radiation therapy (RT) [4-6]. Although there is no consensus regarding the optimal dose of RT, but RT dose $\geq 40$ Gy was reported to improve LC $[4,7]$. Nevertheless, more than half of the patients after local or systemic treatment eventually progress to MM with long-term follow-up $[3,4,8,9]$.

Although there is a consensus criteria for treatment response assessment for multiple myeloma [10], there is no widely used criteria for solitary plasmacytoma. Also, the prediction of treatment failure in solitary plasmacytoma patients is not available although early predictions of treatment failure is important considering the high rates of progressions to $\mathrm{MM}$ in order to make early salvage treatment possible.

Myeloma protein, which is also called M protein, is an abnormal protein produced in excess by an abnormal monoclonal proliferation of plasma cells and is typically detected in serum or urine of patients with $\mathrm{MM}$ or plasma cell tumors. Although only $3 \%$ of MM patients are non-secretory [11], i.e., no detectable serum and urine $\mathrm{M}$ protein at diagnosis, M protein is present in only 33\% to $64 \%$ of solitary plasmacytoma patients at diagnosis $[4,5,12,13]$. Also in patients with $\mathrm{M}$ protein, the median level of serum $\mathrm{M}$ protein at diagnosis of solitary plasmacytoma patients is less than $1 \mathrm{~g} / \mathrm{dL}[5,13]$, which is lower than that of MM (>3 g/dL) [11]. Nevertheless, the measurements of serum $M$ protein level for solitary plasmacytoma is important in that the persistence of serum $\mathrm{M}$ protein after treatment was associated with poor prognosis [12-14] and therefore, the European Expert Panel recommended serum and urine electrophoresis and immunofixation to be performed during follow-up [15].

However, the usefulness of serum M protein as a biomarker to assess treatment response and to predict treatment failures in solitary plasmacytoma is yet to be studied. In MM, randomized trials implemented the increase in serum $M$ protein more than $0.5 \mathrm{~g} / \mathrm{dL}$ from nadir to define disease progression $[16,17]$. Considering the high incidence of non-secretory plasmacytoma and low level of serum $M$ protein level at diagnosis, this criterion seems not to be appropriate for solitary plasmacytoma. Therefore, we tried to identify the clinical usefulness of serum $\mathrm{M}$ protein for predicting treatment failures and to establish a rationale for regular follow-up with serum protein electrophoresis to evaluate serum $\mathrm{M}$ protein level.

\section{Materials and Methods}

\section{Patients and diagnostic work-up}

Medical records of patients with solitary plasmacytoma and solitary plasmacytoma with minimal marrow involvement according to the International Myeloma Working Group (IMWG) criteria [18] were retrospectively reviewed. A total of 69 solitary plasmacytoma patients who were taken care of between 1986 and 2019 at Seoul National University Hospital and Seoul National University Bundang Hospital were identified. At initial diagnostic work-up, all patients were evaluated with at least one radiological imaging workups (100.0\%) including simple X-ray, CT, MRI, bone scan, or FDGPET scan and laboratory work-ups including serum protein electrophoresis (62.3\%), urine protein electrophoresis (55.1\%), and serum free light chain ratio (31.9\%).

The characteristics of all patients are shown in Table 1. The median age at the diagnosis of solitary plasmacytoma was 60.5 years (range, 29.7 to 79.8 years) and male was predominant (59.4\%). The most common initial presenting symptom was pain at the involved site (59.4\%). Vertebra was the most common primary site of the 51 SPB patients. Head and neck was the most common primary site of the 18 SEP patients. At initial diagnostic work-up, serum M protein, Bence Jones proteinuria, and abnormal free light chain ratio was present in $58.1 \%, 15.8 \%$, and $50.0 \%$ of patients whose pre-treatment data was available, respectively. Patients treated with surgery alone or surgery plus adjuvant RT included more patients with insufficient initial work-up studies including serum and urine protein electrophoresis ( $<$ < 0.05) (Supplementary Table S1).

\section{Treatment and follow-up}

All patients received a curative treatment; definitive RT alone (46.4\%), surgical resection (24.6\%), and surgical resection plus adjuvant RT (17.4\%). The median total radiation dose was $45.0 \mathrm{~Gy}$ (range, 23.4 to $70.0 \mathrm{~Gy}$ ). Curative surgical resection was performed in 33 patients (47.8\%) and 90.9\% of them underwent complete resection. Chemotherapy was administered to 8 patients (11.6\%). After the completion of treatment, patients were followed up with work-ups including radiological imaging studies, serum protein electrophoresis, and serum free light chain ratio. The median time from the initial serum protein electrophoresis at the time of diagnosis to first post-treatment serum protein electrophoresis was 3.5 months (range, 1.3 to 36.5 months). In this study, we defined the "disappearance of serum M protein" in order to assess treatment response. When post-treatment serum $M$ protein of a patient whose initial serum $M$ protein was present or not evaluated was measured and showed no detectable serum $M$ protein during follow-up, it was regarded as disappearance of serum $M$ protein.

Patients were defined as progression to $\mathrm{MM}$, whenever meeting the criteria of IMWG for the diagnosis of MM during follow-up [18]. The diagnosis of MM requires clonal bone marrow plasma cells $\geq 10 \%$ or a biopsy-proven plasmacytoma plus the presence of one or more myeloma-defining events. Myeloma defining events include the presence of hypercalcemia, renal insufficiency, anemia, and bone lesion. Also, clonal bone marrow plasma cells $\geq 60 \%$, se- 
Table 1. Patient characteristics of solitary plasmacytoma

\begin{tabular}{|c|c|}
\hline Characteristic & Number of patients (\%) \\
\hline \multicolumn{2}{|l|}{ Age (yr) } \\
\hline$<60$ & $32(46.4)$ \\
\hline$\geq 60$ & 37 (53.6) \\
\hline \multicolumn{2}{|l|}{ Sex } \\
\hline Male & $41(59.4)$ \\
\hline Female & $28(40.6)$ \\
\hline \multicolumn{2}{|l|}{ Site of lesion } \\
\hline SPB & $51(73.9)$ \\
\hline Craniofacial bone & $11(15.9)$ \\
\hline Vertebra & $21(30.4)$ \\
\hline Pelvic bone & $9(23.1)$ \\
\hline Extremity & $4(5.8)$ \\
\hline Others & $6(8.7)$ \\
\hline SEP & $18(26.1)$ \\
\hline Head and neck & $14(20.3)$ \\
\hline Others & $4(5.8)$ \\
\hline \multicolumn{2}{|l|}{ Anaplastic histology } \\
\hline No & $67(97.1)$ \\
\hline Yes & $2(2.9)$ \\
\hline \multicolumn{2}{|l|}{ Serum M protein at diagnosis (g/dL) } \\
\hline 0 & $18(26.1)$ \\
\hline $0.1-1.0$ & $11(15.9)$ \\
\hline$\geq 1.1$ & $14(20.3)$ \\
\hline Unknown & $26(37.7)$ \\
\hline \multicolumn{2}{|l|}{ Type of M protein } \\
\hline $\lg G$ & $18(72.0)$ \\
\hline Light chain only & $2(8.0)$ \\
\hline Unknown & $5(20.0)$ \\
\hline \multicolumn{2}{|l|}{ Bence Jones proteinuria } \\
\hline Absent & $32(46.4)$ \\
\hline Present & $6(8.7)$ \\
\hline Unknown & $31(44.9)$ \\
\hline \multicolumn{2}{|l|}{ Serum free light chain ratio } \\
\hline Normal & $11(15.9)$ \\
\hline Abnormal & $11(15.9)$ \\
\hline Unknown & $47(68.1)$ \\
\hline \multicolumn{2}{|l|}{ Treatment } \\
\hline RT only & $32(46.4)$ \\
\hline Surgery only & $17(24.6)$ \\
\hline Surgery + RT & $12(17.4)$ \\
\hline Chemotherapy alone & $3(4.3)$ \\
\hline $\mathrm{RT}+$ chemotherapy & $2(2.9)$ \\
\hline Surgery + chemotherapy & $1(1.4)$ \\
\hline Surgery + RT + chemotherapy ${ }^{a)}$ & $2(2.9)$ \\
\hline \multicolumn{2}{|l|}{ Radiation therapy ${ }^{b)}$} \\
\hline No radiation therapy & $22(31.9)$ \\
\hline$<45$ GyEOD2 & $31(44.9)$ \\
\hline$\geq 45$ GyEOD2 & $15(21.7)$ \\
\hline \multicolumn{2}{|l|}{ Surgical resection } \\
\hline No surgical resection & $36(52.2)$ \\
\hline Partial resection & $3(7.7)$ \\
\hline Complete resection & $30(43.5)$ \\
\hline
\end{tabular}

SPB, solitary plasmacytoma of bone; SEP, solitary extramedullary plasmacytoma; RT, radiation therapy; EQD2, equivalent dose in 2-Gy fractions at $\alpha / \beta$ of 10 .

${ }^{a}$ One patient received additional radiosurgery.

${ }^{b)}$ One patient with unknown dose excluded. rum free light chain ratio $\geq 100$, or more than one focal lesion on $\mathrm{MRI}$ are diagnosed as MM regardless of the presence of myeloma defining event.

\section{Statistical analysis}

The characteristics according to various treatments were compared using Fisher's exact test. The actuarial LC, multiple myeloma-free survival (MMFS), failure-free survival (FFS), and overall survival (OS) were calculated with Kaplan-Meier analysis. All survivals were calculated from the first day of initial treatment. The events were local failure before progression to $\mathrm{MM}$ for $\mathrm{LC}$, progression to $\mathrm{MM}$ or death from any cause for MMFS, any failure or death from any cause for FFS, and death from any cause for OS. Log-rank test was used for univariate analysis of the prognostic factors. Based on prognostic factors with $p<0.05$, multivariate analysis was conducted. To identify a set of independent predictive factors a multivariate analysis with Cox proportional hazards model or Cox regression with Firth's penalized likelihood was performed as appropriate. In all analyses $p<0.05$ was considered statistically significant. All statistical analyses were conducted in $\mathrm{R}$ version 3.5.0.

\section{Results}

\section{Survival outcome and cause of death}

At a median follow-up of 6.8 years (range, 0.1 to 29.3 years), 9 patients (13.0\%) experienced a local failure; 8 within 3 years and one at 9 years after treatment (Fig. 1A). The 5 - and 10 -year LC rate were $82.6 \%$ and $68.9 \%$. The LC rates did not differ significantly across treatment modalities. Anaplastic plasmacytoma was the only prognostic factor for LC (Table 2, 3). In the meanwhile, RT improved LC for extramedullary lesions (100.0\% vs. 53.6\%; $p=$ 0.028).

Overall, 32 patients (46.8\%) progressed to MM. Most of the progressions to $\mathrm{MM}$ (96.9\%) occurred within the first 5 years after treatment. The 5- and 10-year MMFS were 44.1\% and 36.7\%. In univariate analysis and multivariate analysis, SPB (hazard ratio [HR] $=8.63, p=0.036)$, tumor size $\geq 5 \mathrm{~cm}(H R=2.84, p=0.012)$, and anaplastic histology ( $H R=50.9, p=0.002)$ were adverse prognostic factors for MMFS (Tables 2, 3). The 5- and 10-year FFS were $41.8 \%$ and $34.9 \%$. As they were for MMFS, SPB $(H R=10.3$, $p=0.023)$, tumor size $\geq 5 \mathrm{~cm}(H R=2.18, p=0.043)$, and anaplastic histology ( $H R=66.6, p=0.001)$ were significant adverse prognostic factors for FFS in the univariate and multivariate analysis (Tables 2, 3). The median OS was 14.0 years (95\% confidence interval $[\mathrm{Cl}], 11.8$ years to upper limit not reached). The $5-$ and $10-$ year OS were $85.1 \%$ and $70.6 \%$. There was no significant prognostic factor for OS (Table 4). 


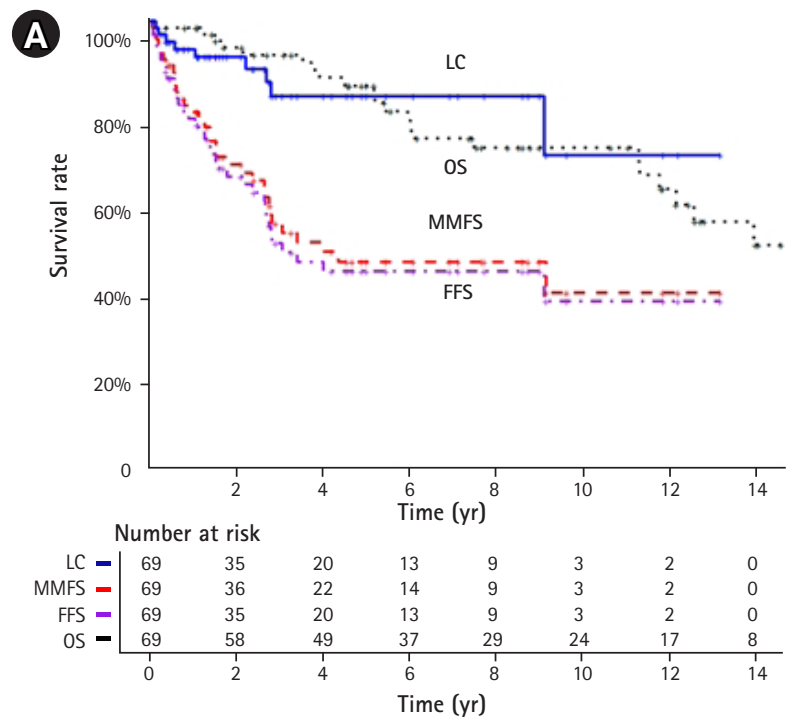

C

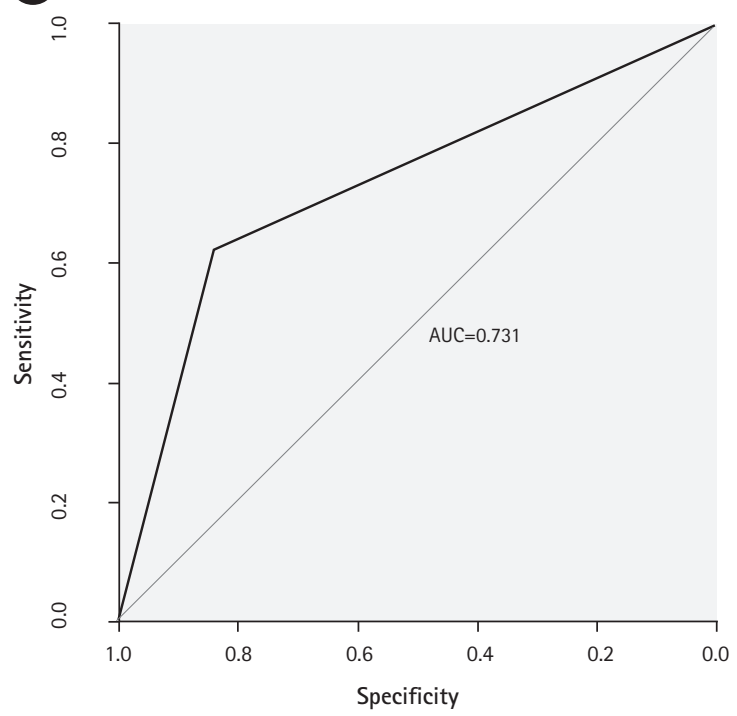

At the time of the analysis, 22 deaths (31.9\%) were reported, and 6 patients died from the progression of MM. There were two deaths related to treatments; one from complications after surgical resection and another from side effects of salvage chemotherapy. Five deaths were unrelated to plasmacytoma or treatment and the cause of death of remaining 9 patients was unknown.

\section{Prognostic factors in patients treated with RT}

In the subgroup of patients treated with any treatment that includes RT, tumor location, tumor size, and serum free light chain ratio were significant prognostic factors for MMFS and FFS in the univariate analysis. In the multivariate analysis, SPB (HR $=22.1, p$ $<0.001)$, tumor size $\geq 5 \mathrm{~cm}(H R=2.64, p=0.045)$, and abnormal serum free light chain ratio $(H R=6.29, p=0.008)$ were associated with poor MMFS. For FFS, SPB $(H R=22.7, p<0.001)$

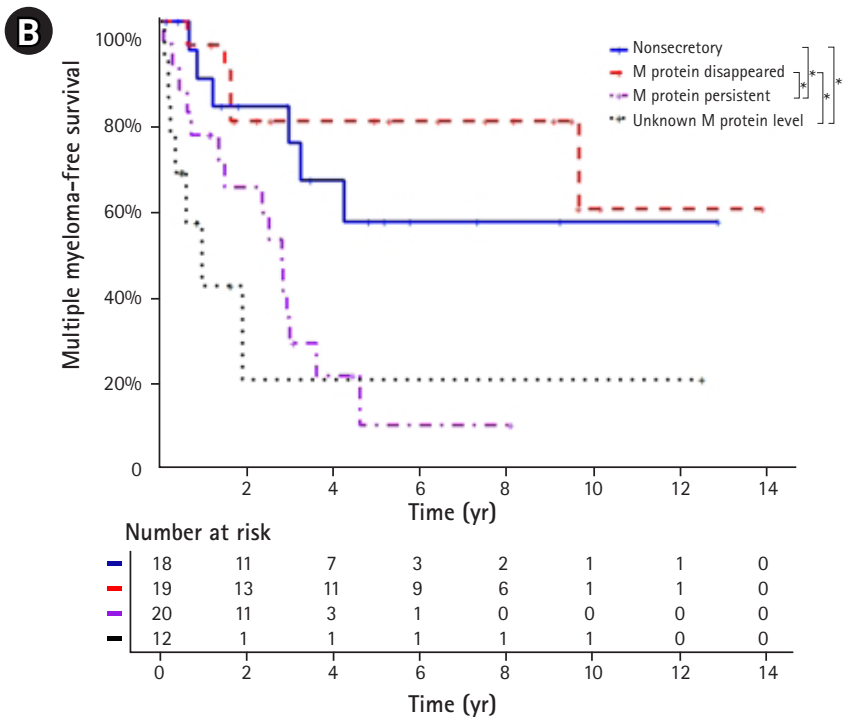

Fig. 1. (A) Treatment outcomes of solitary plasmacytoma after various treatments. (B) Multiple myeloma-free survival of solitary plasmacytoma after various treatment with respect to serum $\mathrm{M}$ protein. (C) Receiver operating characteristic (ROC) curve and area under the curve (AUC) of increase of serum M protein level $\geq 0.1 \mathrm{~g} / \mathrm{dL}$ from current nadir to predict treatment failure. LC, local control; MMFS, multiple myeloma-free survival; FFS, failure-free survival; OS, overall survival. ${ }^{*} p<0.05$.

and abnormal serum free light chain ratio $(H R=7.38, p=0.003)$ were statistically significant adverse prognostic factors. However, there were no significant prognostic factors identified for LC and OS for patients treated with RT. The addition of surgical resection, chemotherapy, or RT dose $\geq 45$ GyEQD2 did not result in significantly improved prognosis.

\section{Disappearance of serum $M$ protein after treatment as a prognostic factor}

At the time of diagnosis, 18 patients were non-secretory. Among the remaining 51 patients who had serum $\mathrm{M}$ protein or whose pre-treatment serum $M$ protein level was not evaluated, serum $M$ protein disappeared in 19 patients after a median period of 2.4 months (range, 0.0 to 51.1 months) following treatment. The 5-year MMFS of patients with non-secretory plasmacytoma, disap- 
Table 2. Risk factors associated with treatment outcome of solitary plasmacytoma (univariate analysis)

\begin{tabular}{|c|c|c|c|c|c|c|c|c|c|}
\hline & $\begin{array}{l}\text { Number of } \\
\text { patients }\end{array}$ & 5-yr LC (\%) & $p$-value & 5-yr MMFS (\%) & $p$-value & 5-yr FFS (\%) & $p$-value & $5-y r$ OS (\%) & $p$-value \\
\hline \multicolumn{10}{|l|}{ Age (yr) } \\
\hline$<60$ & 32 & 68.7 & 0.150 & 40.8 & 0.680 & 37.3 & 0.550 & 89.5 & 0.320 \\
\hline$\geq 60$ & 37 & 94.3 & & 47.4 & & 45.9 & & 81.5 & \\
\hline \multicolumn{10}{|l|}{ Sex } \\
\hline Male & 41 & 72.5 & 0.130 & 37.4 & 0.220 & 34.0 & 0.098 & 85.8 & 0.190 \\
\hline Female & 28 & 94.4 & & 53.4 & & 53.4 & & 84.2 & \\
\hline \multicolumn{10}{|l|}{ Tumor location } \\
\hline Extramedullary & 18 & 80.2 & 0.820 & 80.2 & 0.007 & 80.2 & 0.004 & 94.4 & 0.120 \\
\hline Bone & 51 & 82.9 & & 32.1 & & 29.4 & & 81.2 & \\
\hline \multicolumn{10}{|l|}{ Tumor size $(\mathrm{cm})$} \\
\hline$<5$ & 33 & 83.8 & 0.710 & 70.2 & $<0.001$ & 63.7 & 0.001 & 93.2 & 0.076 \\
\hline$\geq 5$ & 30 & 87.1 & & 22.6 & & 22.8 & & 74.9 & \\
\hline \multicolumn{10}{|c|}{ Anaplastic histology } \\
\hline No & 67 & 85.4 & $<0.001$ & 45.5 & 0.001 & 43.1 & $<0.001$ & 84.6 & 0.260 \\
\hline Yes & 2 & 0.0 & & 0.0 & & 0.0 & & 100.0 & \\
\hline \multicolumn{10}{|c|}{ Serum M protein present } \\
\hline No & 18 & 90 & 0.470 & 55.7 & 0.220 & 55.7 & 0.130 & 87.1 & 0.650 \\
\hline Yes & 25 & 85.2 & & 27.3 & & 29.2 & & 79.8 & \\
\hline Unknown & 26 & 77.0 & & 47.8 & & 43.1 & & 88.1 & \\
\hline \multicolumn{10}{|c|}{ Bence Jones proteinuria } \\
\hline Absent & 32 & 88.0 & 0.160 & 37.9 & 0.820 & 39.2 & 0.790 & 85.2 & 0.890 \\
\hline Present & 6 & 100.0 & & 50.0 & & 50.0 & & 100.0 & \\
\hline Unknown & 31 & 74.1 & & 49.1 & & 43.2 & & 82.9 & \\
\hline \multicolumn{10}{|c|}{ Serum free light chain ratio } \\
\hline Normal & 11 & 100.0 & 0.320 & 67.5 & 0.046 & 67.5 & 0.019 & 90 & 0.910 \\
\hline Abnormal & 11 & 78.8 & & 21.8 & & 18.2 & & 75.0 & \\
\hline Unknown & 47 & 79.6 & & 45.2 & & 43.0 & & 86.3 & \\
\hline \multicolumn{10}{|l|}{ Treatment } \\
\hline RT alone & 32 & 79.8 & 0.340 & 31.3 & 0.560 & 31.4 & 0.530 & 83.6 & 0.260 \\
\hline Surgery alone & 17 & 72.9 & & 55.8 & & 49.0 & & 94.1 & \\
\hline Surgery + RT & 12 & 100 & & 50.9 & & 50.9 & & 75.0 & \\
\hline
\end{tabular}

LC, local control; MMFS, multiple myeloma-free survival; FFS, failure-free survival; OS, overall survival; RT, radiation therapy.

Table 3. Risk factors associated with treatment outcome of solitary plasmacytoma (multivariate analysis)

\begin{tabular}{|c|c|c|c|c|c|c|}
\hline & \multicolumn{2}{|c|}{ LC } & \multicolumn{2}{|c|}{ MMFS } & \multicolumn{2}{|c|}{ FFS } \\
\hline & HR (95\% Cl) & $p$-value & HR (95\% Cl) & $p$-value & HR (95\% Cl) & $p$-value \\
\hline \multicolumn{7}{|l|}{ Tumor location } \\
\hline Extramedullary & - & & Ref. & 0.036 & Ref. & 0.023 \\
\hline Bone & - & & $8.63(1.15-64.9)$ & & $10.28(1.37-76.9)$ & \\
\hline \multicolumn{7}{|l|}{ Size of lesion (cm) } \\
\hline$<5$ & - & & Ref. & 0.012 & Ref. & 0.043 \\
\hline$\geq 5$ & - & & $2.84(1.26-6.42)$ & & $2.18(1.03-4.65)$ & \\
\hline \multicolumn{7}{|l|}{ Anaplastic histology } \\
\hline No & Ref. & $<0.001$ & Ref. & 0.002 & Ref. & 0.001 \\
\hline Yes & $50.6(7.01-366)$ & & $50.9(4.14-626)$ & & 66.6 (5.39-822) & \\
\hline
\end{tabular}

LC, local control; MMFS, multiple myeloma-free survival; $F F S$, failure-free survival; $\mathrm{HR}$, hazard ratio; $\mathrm{Cl}$, confidence interval. 
pearance of serum $M$ protein, persistence of serum $M$ protein, and unknown post-treatment serum $\mathrm{M}$ protein level were $55.7 \%$, 78.0\%, 10.8\%, and 20.8\%, respectively (Fig. 1B). The MMFS of non-secretory plasmacytoma patients and patients whose serum $M$ protein disappeared were comparable ( $p>0.05$ ). Both groups of patients showed significantly superior 5-year MMFS compared to patients who showed persistence of serum $M$ protein and patients whose serum $\mathrm{M}$ protein level was not evaluated during follow-up ( $\mathrm{p}$ $<0.05)$.

\section{Correlation of disappearance of serum M protein and RT}

Among patients who initially had serum M protein, the post-treatment serum M protein level was available from 20 patients. Two patients who did not receive RT showed persistence of serum M protein after treatment, whereas disappearance of serum $\mathrm{M}$ protein was observed in 7 patients (38.9\%) after RT (Table 3). The rates of disappearance of serum $\mathrm{M}$ protein were $25.0 \%$ and $66.7 \%$ with RT dose $<45$ GyEQD2 and $\geq 45$ GyEQD2, respectively.

\section{The increase of serum $M$ protein level as a predictive marker for treatment failure}

Next, we tried to predict treatment failures with the level change of serum M protein. Overall, 40 patients were followed up with at least two serum protein electrophoresis tests during follow-up before any treatment failure, defined as local failure and progression to MM. The median value of post-treatment nadir value of serum $\mathrm{M}$ protein was $0.0 \mathrm{~g} / \mathrm{dL}$ (range, 0.0 to $3.2 \mathrm{~g} / \mathrm{dL}$ ). During follow-up, 17 patients experienced an increase of serum $M$ protein level at

Table 4. Correlation of disappearance of serum $\mathrm{M}$ protein and radiation therapy

\begin{tabular}{lccc}
\hline \multirow{2}{*}{ RT dose ${ }^{\text {a) }}$} & $\begin{array}{c}\text { Number of } \\
\text { patients }\end{array}$ & \multicolumn{2}{c}{ Serum M protein } \\
\cline { 3 - 4 } & 2 & $0(0.0)$ & Disappearance $(\%)$ \\
\hline No RT & 12 & $3(25.0)$ & $9(70.0)$ \\
$<45$ GyEQD2 & 6 & $4(66.7)$ & $2(33.3)$ \\
\hline 45 GyEQD2 & &
\end{tabular}

$\mathrm{RT}$, radiation therapy; EQD2, equivalent dose in 2-Gy fractions at $\alpha / \beta$ of 10.

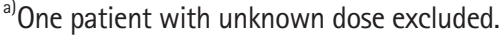

least once before clinically detected treatment failure. The median of maximum increase of serum $\mathrm{M}$ protein from nadir was 0.7 (range, 0.02 to $2.1 \mathrm{~g} / \mathrm{dL}$ ).

Considering the high incidence of non-secretory $\mathrm{M}$ protein and low level of serum M protein in solitary plasmacytoma at diagnosis, we evaluated the increase of serum M protein level $\geq 0.1 \mathrm{~g} / \mathrm{dL}$ from current nadir instead of $0.5 \mathrm{~g} / \mathrm{dL}$, which is implemented in $\mathrm{MM}$, to predict treatment failure. The area under the curve (AUC) of the prediction model with this criterion was 0.731 (Table 5, Fig. 1C). Specificity and sensitivity of this model were $84.2 \%$ and $61.9 \%$, respectively. The median time to treatment failure from the day serum $M$ protein level increased $0.1 \mathrm{~g} / \mathrm{dL}$ or more from current nadir was 16.9 months (95\% Cl, 6.9 months to upper limit not reached).

In addition, three other criteria were evaluated, which are two increases of serum $M$ protein level, two consecutive increases of serum $\mathrm{M}$ protein level, and increase of serum $\mathrm{M}$ protein above double the value of nadir. The AUC of the prediction models with these criteria were $0.690,0.662$, and 0.614 , respectively (Table 5 ). As the increase of serum $M$ protein level $\geq 0.1 \mathrm{~g} / \mathrm{dL}$ from current nadir showed highest AUC amongst the four criteria compared, we adopted this criterion to predict treatment failure.

\section{Discussion and Conclusion}

In this study, we evaluated the prognostic value of serum $\mathrm{M}$ protein level at diagnosis and its level change or conversion during follow-up to assess treatment response and predict treatment failures of solitary plasmacytoma.

Prognostic factors with contradictory prognostic values for solitary plasmacytoma were demonstrated in previous studies due to different treatment profiles and small number of patients included in each study. Although local control was excellent in this study and was also consistent with that of previous studies, progression to MM remained to be the main obstacle for failure-free survival as observed in Fig. 1A. In this study, SPB and tumor size $\geq 5 \mathrm{~cm}$ were associated with poor MMFS and FFS, which is consistent with the results of previous studies $[3,5,8,9,19,20]$. Older age $[3,5,19-21]$, the abnormal post-treatment free light chain ratio [12], the pres-

Table 5. Correlation of various increases of serum $\mathrm{M}$ proteins with treatment failure

\begin{tabular}{lccccc}
\hline & Number of patients (\%) & Sensitivity (\%) & Specificity (\%) & AUC & Median time to treatment failure (mo) \\
\hline Increase $\geq 0.1 \mathrm{~g} / \mathrm{dL}$ from current nadir & $16(40.0)$ & 61.9 & 84.2 & 0.731 & 16.9 \\
Two increases & $13(37.1)$ & 55.6 & 82.4 & 0.690 & 20.8 \\
Two consecutive increases & $12(34.3)$ & 50.0 & 82.4 & 0.662 & 17.4 \\
Increase double above nadir & $9(22.5)$ & 33.3 & 89.5 & 0.614 & 4.0
\end{tabular}

AUC, area under the curve. 
ence of serum M protein at diagnosis [5] and after treatment [12] were also suggested to be associated with poor prognosis. Warsame et al. [22] reported clonal plasma cells in BM, presence of urine Bence Jones protein, and higher RT dose as adverse prognostic factors for progression-free survival.

In addition to SPB and tumor size $\geq 5 \mathrm{~cm}$, anaplastic plasmacytoma was associated with poor LC, MMFS, and FFS. Anaplastic plasmacytoma is an extremely rare type of plasmacytoma which can develop in patients with immunosuppression and combined Epstein-Barr virus infection [23]. However, because of its rarity the clinical course of anaplastic plasmacytoma is unknown. In this study, two patients of anaplastic plasmacytoma were included and they showed rapid local failure and progression to MM. However, both patients survived more than 10 years. It seems that anaplastic plasmacytoma shows rapid progression but does not result in poor overall survival, but the clinical course of anaplastic plasmacytoma needs to be investigated with larger number of patients.

In this study, patients with non-secretory plasmacytoma and patients whose serum $M$ protein disappeared after treatment showed superior MMFS compared to patients who had persistent serum M protein after treatment. However, the prognostic value of serum $M$ protein level at diagnosis is controversial. Non-secretory plasmacytoma showed better MMFS in the study by Reed et al. [5], whereas the opposite result showing that non-secretory plasmacytoma is associated with worse MMFS and cause-specific survival was also reported $[13,14]$. In contrast, the persistence of $M$ protein after treatment is uniformly reported to be associated with poor MMFS [12-14], which was also observed in this current study. Moreover, we showed the usefulness of the increase of serum $M$ protein level $\geq 0.1 \mathrm{~g} / \mathrm{dL}$ from current nadir for predicting treatment failures. Therefore, it would be reasonable to follow-up patients, who initially had serum $M$ protein or whose pre-treatment serum $M$ protein level was not evaluated, with a regular serum protein electrophoresis test along with radiologic examinations until the serum $M$ protein disappears. In addition, even if patients had non-secretory disease or their serum $M$ protein disappeared, a regular follow-up with serum protein electrophoresis would be needed in order to make earlier detection and salvage treatment possible.

Immunofixation and free light chain ratio are another tests to evaluate serum M protein. It has been reported that $9.7 \%$ of normal serum protein electrophoresis showed positive immunofixation result [24] and therefore, immunofixation could be a good complementary test when combined with serum protein electrophoresis during follow-up. Abnormal serum free light chain ratio was a significant prognostic factor in patients who were treated with RT in our study and in a previous study [12]. Considering this, serum free light chain ratio could be another potential predictive biomarker to be investigated and utilized.

RT has been known as the treatment of choice for solitary plasmacytoma $[15,25,26]$ with evidences from retrospective studies showing improved LC [3], disease-free survival [3], and OS [2] with RT. Regarding the dose of RT, higher doses were recommended for SEP [27] and larger tumors [19], although no definite dose-response relationship for RT > 30 Gy was observed in another study [3]. In this study, we also could not find a definite dose-response relationship. However, RT $\geq 45$ GyEQD2 seemed to increase the rates of disappearance of serum $\mathrm{M}$ protein, which can be interpreted as good treatment response, although the number of patients were insufficient to show definite relationship.

In this study, since solitary plasmacytoma without evidence of $\mathrm{MM}$ is very rare in nature, we could find only a small number of patients. Patients who were incidentally diagnosed as solitary plasmacytoma after surgical resection lacked the pre-treatment workup for solitary plasmacytoma as shown in Supplementary Table S2. Therefore, our definition of disappearance of serum M protein included patients whose initial serum $M$ protein level was not evaluated when predicting the prognosis with respect to serum $M$ protein level. However, considering that it is often the case that solitary plasmacytoma is incidentally diagnosed after surgery, as it was in this study, it would be still meaningful to include patients whose initial serum $M$ protein was not evaluated and predict their prognosis. Also, the data of proportion of clonal plasma cells in the bone marrow was not available in $46.4 \%$ of the patients and therefore, we could not show any prognostic difference between solitary plasmacytoma and solitary plasmacytoma with minimal marrow involvement according to the IMWG criteria. However, with long-term follow-up data, we could derive a meaningful conclusion regarding the clinical value of serum $\mathrm{M}$ protein level, although further studies with larger number of patients are needed for validation.

In conclusion, we found that patients who eventually showed persistent serum $\mathrm{M}$ protein after treatment had worse prognosis compared to those whose serum M protein disappeared or initially had non-secretory disease. Also, the increase of serum $M$ protein level $\geq 0.1 \mathrm{~g} / \mathrm{dL}$ from current nadir was predictive of treatment failure. Therefore, we recommend a regular follow-up with serum protein electrophoresis after the treatment of solitary plasmacytoma to assess treatment response and predict treatment failure. Also, closer follow-up with serum protein electrophoresis is needed for patients who initially had serum $M$ protein or whose serum $M$ protein level was not evaluated. 


\section{Conflict of Interest}

No potential conflict of interest relevant to this article was reported.

\section{Supplementary Materials}

Supplementary materials can be found via https://doi.org/10.3857/ roj.2019.00570

Table S1. Risk factors associated with treatment outcome of solitary plasmacytoma treated with RT (univariate analysis)

Table S2. Characteristic of the patients according to their treatments

\section{References}

1. Knowling MA, Harwood AR, Bergsagel DE. Comparison of extramedullary plasmacytomas with solitary and multiple plasma cell tumors of bone. J Clin Oncol 1983;1:255-62.

2. Thumallapally N, Meshref A, Mousa M, Terjanian T. Solitary plasmacytoma: population-based analysis of survival trends and effect of various treatment modalities in the USA. BMC Cancer 2017;17:13.

3. Ozsahin M, Tsang RW, Poortmans P, et al. Outcomes and patterns of failure in solitary plasmacytoma: a multicenter Rare Cancer Network study of 258 patients. Int J Radiat Oncol Biol Phys 2006;64:210-7.

4. Suh YG, Suh CO, Kim JS, Kim SJ, Pyun HO, Cho J. Radiotherapy for solitary plasmacytoma of bone and soft tissue: outcomes and prognostic factors. Ann Hematol 2012;91:1785-93.

5. Reed V, Shah J, Medeiros U, et al. Solitary plasmacytomas: outcome and prognostic factors after definitive radiation therapy. Cancer 2011;117:4468-74.

6. Sasaki R, Yasuda K, Abe E, et al. Multi-institutional analysis of solitary extramedullary plasmacytoma of the head and neck treated with curative radiotherapy. Int J Radiat Oncol Biol Phys 2012;82:626-34.

7. Mendenhall CM, Thar TL, Million RR. Solitary plasmacytoma of bone and soft tissue. Int J Radiat Oncol Biol Phys 1980;6:1497501.

8. Finsinger P, Grammatico S, Chisini M, Piciocchi A, Foa R, Petrucci MT. Clinical features and prognostic factors in solitary plasmacytoma. Br J Haematol 2016;172:554-60.

9. Dagan R, Morris CG, Kirwan J, Mendenhall WM. Solitary plasmacytoma. Am J Clin Oncol 2009;32:612-7.

10. Kumar S, Paiva B, Anderson KC, et al. International Myeloma Working Group consensus criteria for response and minimal re- sidual disease assessment in multiple myeloma. Lancet Oncol 2016;17:e328-e346.

11. Kyle RA, Gertz MA, Witzig TE, et al. Review of 1027 patients with newly diagnosed multiple myeloma. Mayo Clin Proc 2003;78:2133.

12. Dingli D, Kyle RA, Rajkumar SV, et al. Immunoglobulin free light chains and solitary plasmacytoma of bone. Blood 2006;108: 1979-83.

13. Liebross RH, Ha CS, Cox JD, Weber D, Delasalle K, Alexanian R. Solitary bone plasmacytoma: outcome and prognostic factors following radiotherapy. Int J Radiat Oncol Biol Phys 1998; 41:1063-7.

14. Wilder RB, Ha CS, Cox JD, Weber D, Delasalle K, Alexanian R. Persistence of myeloma protein for more than one year after radiotherapy is an adverse prognostic factor in solitary plasmacytoma of bone. Cancer 2002;94:1532-7.

15. Caers J, Paiva B, Zamagni $E_{1}$ et al. Diagnosis, treatment, and response assessment in solitary plasmacytoma: updated recommendations from a European Expert Panel. J Hematol Oncol 2018;11:10.

16. Dimopoulos M, Spencer A, Attal M, et al. Lenalidomide plus dexamethasone for relapsed or refractory multiple myeloma. $\mathrm{N}$ Engl J Med 2007;357:2123-32.

17. Weber DM, Chen C, Niesvizky R, et al. Lenalidomide plus dexamethasone for relapsed multiple myeloma in North America. N Engl J Med 2007;357:2133-42.

18. Rajkumar SV, Dimopoulos MA, Palumbo A, et al. International Myeloma Working Group updated criteria for the diagnosis of multiple myeloma. Lancet Oncol 2014;15:e538-48.

19. Tsang RW, Gospodarowicz MK, Pintilie M, et al. Solitary plasmacytoma treated with radiotherapy: impact of tumor size on outcome. Int J Radiat Oncol Biol Phys 2001;50:113-20.

20. Knobel D, Zouhair A, Tsang RW, et al. Prognostic factors in solitary plasmacytoma of the bone: a multicenter Rare Cancer Network study. BMC Cancer 2006;6:118.

21. Goyal G, Bartley AC, Funni S, et al. Treatment approaches and outcomes in plasmacytomas: analysis using a national dataset. Leukemia 2018;32:1414-20.

22. Warsame R, Gertz MA, Lacy MQ, et al. Trends and outcomes of modern staging of solitary plasmacytoma of bone. Am J Hematol 2012;87:647-51.

23. Papadaki HA, Stefanaki K, Kanavaros P, et al. Epstein-Barr virus-associated high-grade anaplastic plasmacytoma in a renal transplant patient. Leuk Lymphoma 2000;36:411-5.

24. Lakshminarayanan R, Li Y, Janatpour K, Beckett L, Jialal I. Detection by immunofixation of $\mathrm{M}$ proteins in hypogammaglobulinemic patients with normal serum protein electrophoresis results. 
Am J Clin Pathol 2007;127:746-51.

25. Soutar R, Lucraft $H$, Jackson $G$, et al. Guidelines on the diagnosis and management of solitary plasmacytoma of bone and solitary extramedullary plasmacytoma. Br J Haematol 2004;124:717-26.

26. Tsang RW, Campbell BA, Goda JS, et al. Radiation Therapy for Solitary Plasmacytoma and Multiple Myeloma: Guidelines From the International Lymphoma Radiation Oncology Group. Int J
Radiat Oncol Biol Phys 2018;101:794-808.

27. Tournier-Rangeard L, Lapeyre M, Graff-Caillaud P, et al. Radiotherapy for solitary extramedullary plasmacytoma in the headand-neck region: a dose greater than $45 \mathrm{~Gy}$ to the target volume improves the local control. Int J Radiat Oncol Biol Phys 2006; 64:1013-7. 